University of Nebraska - Lincoln

DigitalCommons@University of Nebraska - Lincoln

Publications, Agencies and Staff of the U.S.

Department of Commerce

U.S. Department of Commerce

1995

Initial Colonization of the Zebra Mussel (Dreissena polymorpha) in

Saginaw Bay, Lake Huron: Population Recruitment, Density, and

Size Structure

\author{
Thomas F. Nalepa \\ Great Lakes Environmental Research Laboratory, thomas.nalepa@noaa.gov \\ James A. Wojcik \\ University of Michigan - Ann Arbor \\ David L. Fanslow \\ Great Lakes Environmental Research Laboratory \\ Gregory A. Lang \\ Great Lakes Environmental Research Laboratory
}

Follow this and additional works at: https://digitalcommons.unl.edu/usdeptcommercepub

Part of the Environmental Sciences Commons

Nalepa, Thomas F.; Wojcik, James A.; Fanslow, David L.; and Lang, Gregory A., "Initial Colonization of the Zebra Mussel (Dreissena polymorpha) in Saginaw Bay, Lake Huron: Population Recruitment, Density, and Size Structure" (1995). Publications, Agencies and Staff of the U.S. Department of Commerce. 394. https://digitalcommons.unl.edu/usdeptcommercepub/394

This Article is brought to you for free and open access by the U.S. Department of Commerce at DigitalCommons@University of Nebraska - Lincoln. It has been accepted for inclusion in Publications, Agencies and Staff of the U.S. Department of Commerce by an authorized administrator of DigitalCommons@University of Nebraska - Lincoln. 


\title{
Initial Colonization of the Zebra Mussel (Dreissena polymorpha) in Saginaw Bay, Lake Huron: Population Recruitment, Density, and Size Structure
}

\author{
Thomas F. Nalepa, ${ }^{1}$ James A. Wojcik, ${ }^{2}$ David L. Fanslow, ${ }^{1}$ and Gregory A. Lang ${ }^{1}$ \\ ${ }^{1}$ Great Lakes Environmental Research Laboratory \\ 2205 Commonwealth Blvd. \\ Ann Arbor, Michigan 48105 \\ ${ }^{2}$ Cooperative Institute for Limnology and Ecosystems Research \\ University of Michigan \\ 2200 Bonisteel Blvd. \\ Ann Arbor, Michigan 48109
}

\begin{abstract}
The various life stages of the zebra mussel (Dreissena polymorpha) were examined during the initial years (1991-93) of the mussel's invasion into Saginaw Bay, Lake Huron. Yearly trends in densities of larvae, newly-settled juveniles, and adults were poorly related. Larval densities were lowest in 1991 and increased each year, but the number of settled juveniles was highest in 1991. Adults increased between 1991 and 1992 and then declined in 1993. Mean adult densities at sites with hard substrates were $11,700,33,200$, and $4,100 / \mathrm{m}^{2}$ in each of the 3 years, respectively. Year-to-year variation at individual sites was high and likely a result of recruitment dynamics and spatial patchiness of available substrate. By 1993, densities on hard substrates were generally similar throughout the bay, but length-frequency distributions in the inner and outer bay were quite different. The 1991-cohort was not distinguishable in the inner bay in 1993 either because of poor growth or a limited life span, but this cohort was readily distinguishable in the outer bay. In addition, ash-free dry weight of a standard 15-mm mussel in the inner bay declined 65\% between 1991 and 1993. Although food concentrations (chlorophyll and particulate organic carbon) declined to low levels in 1993 and both densities and soft-tissue weight of Dreissena declined, it is not clear whether populations in the bay have peaked and are now at equilibrium with the surrounding environment.
\end{abstract}

INDEX WORDS: Zebra mussels, recruitment, population, Lake Huron.

\section{INTRODUCTION}

Since the zebra mussel (Dreissena polymorpha) first became established in the Great Lakes, a number of changes in water quality parameters have been documented in regions where the mussels have become most abundant. Recent increases in water clarity, declines in chlorophyll levels, and lower phytoplankton abundances have mainly been attributed to the filtering activity of the mussels (Hebert $e t$ al. 1991, Holland 1993, Leach 1993, Nicholls and Hopkins 1993, Marsden et al. 1993). While the evidence for mussel-induced changes seems convincing, others have suggested that at least a portion of these changes can be attributed to such factors as zooplankton grazing or nutrient abatement programs (Wu and Culver 1991, Nicholls and Hopkins 1993).
Fundamental to understanding the impact of Dreissena on a given ecosystem is an accurate, realistic estimate of population standing stocks. However, Dreissena populations are highly variable in both space and time, and obtaining accurate population estimates for a given system is often a difficult task. Densities can vary greatly over limited distances due to differences in substrate type and other physical and chemical features of the particular habitat (Dermott and Munawar 1993, Mellina and Rasmussen 1994). In addition to varying over space, populations can vary from year to year in response to factors that are extrinsic to the specific habitat, or to factors that are density dependent. These temporal fluctuations can be divided into two categories: those associated with the initial invasion, and those 
associated with an already established population (Stanczykowska and Lewandowski 1993). The former category is typified by an initial high density followed by a population crash (Sebestyen 1938, Walz 1974), and the latter by irregular increases and decreases over several decades (Stanczykowska et al. 1975).

As part of an assessment of the impact of Dreissena on the Saginaw Bay ecosystem, we here document temporal trends and spatial distributions of populations in 1991, 1992, and 1993. Although mussels were found in the bay in 1990 , the first large recruitment did not occur until summer 1991, thus densities over the study period reflect trends during the initial years of the invasion. In addition to documenting density trends of the various life stages (larvae, newly-settled juveniles, and adults) over this period, two important features of the adult population were also examined: soft tissue weight per unit shell length and length-frequency distribution. In mollusks, the weight:length relationship provides a measure of the relative condition or nutritional state of the population (Russell-Hunter $e t$ al. 1984, Russell-Hunter 1985) and has been used to assess physiological stress in Dreissena (Stanczykowska 1964, Nalepa et al. 1993). The length-frequency distribution provides information on growth and survival of individual cohorts (Griffiths et al. 1991, Mackie 1991). In examining density trends and growth patterns, emphasis was placed on comparing populations in two regions of the bay, the eutrophic inner bay and the oligotrophic outer bay.

\section{Description of Study Site}

Saginaw Bay is a shallow, well-mixed extension of the western shoreline of Lake Huron. Total area of the bay is $2.77 \times 10^{9} \mathrm{~m}^{2}$, and total water volume is $24.54 \times 10^{9} \mathrm{~m}^{3}$. The bay can be divided into an inner and outer region by a line extending along its narrowest width $(21 \mathrm{~km})$ from Sand Point to Point Lookout (Fig. 1). A broad shoal and several islands along this line provide a natural demarcation between the two regions. Differences in physical and chemical features of the inner and outer bay regions are distinct (Beeton et al. 1967, Smith et al. 1977). The inner bay has a mean depth of only $5.1 \mathrm{~m}$, is nutrient-rich, and is heavily influenced by input from the Saginaw River, which accounts for $70 \%$ of the total tributary flow into the bay. The outer bay has a mean depth of $13.7 \mathrm{~m}$ and is more influenced by the colder, nutrient-poor waters of Lake Huron.

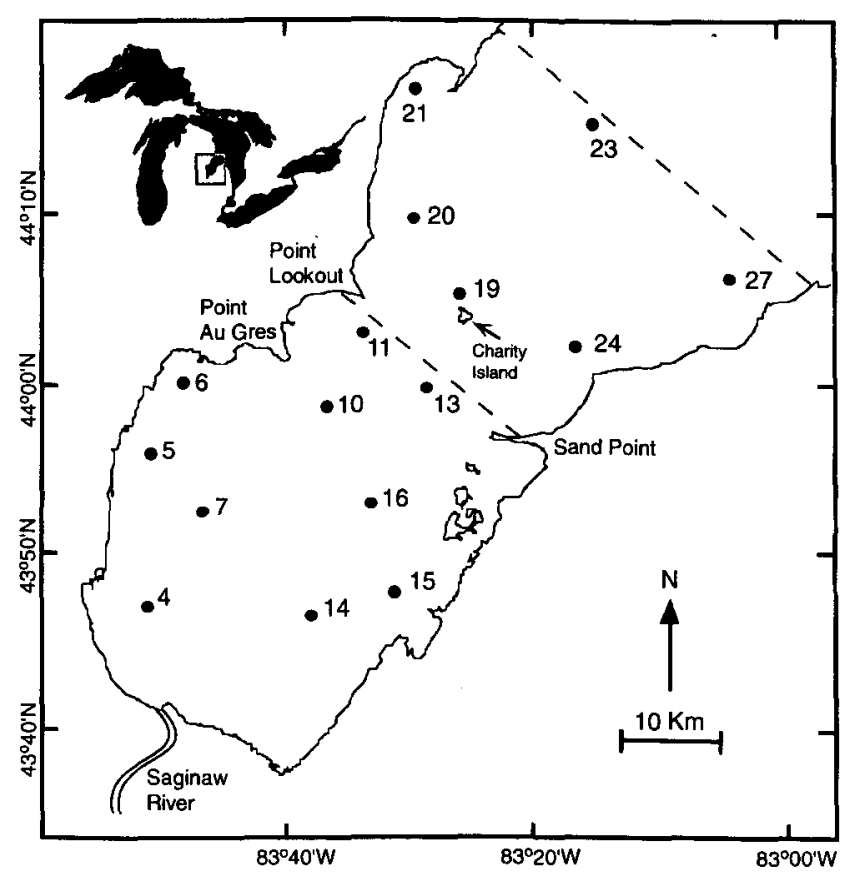

FIG. 1. Location of sampling sites in Saginaw Bay, 1991-1993. Dashed lines differentiate the inner bay from the outer bay and the outer bay from Lake Huron.

Bottom substrates in Saginaw Bay range from silt to mostly cobble and rock. The inner bay has a wide sand-gravel bar that extends along the eastern side of the bay from the Saginaw River to the Charity Islands. Another sand-gravel bar extends along the western shoreline to Point Au Gres. Both sand bars have irregular areas of cobble along with patches of sand, gravel, and pebbles. The bars extend into the shorelines as extensive flats grade into marshes. Between the two sand bars is an area of maximum depth where the substrate consists of fine-grained sediments (silt/mud). Based on areal estimates of substrate type by Wood (1964) and extensive benthic sampling in the late 1980s (Nalepa unpublished), we estimated that $70 \%$ of the bottom in the inner bay consists of sand, gravel, and cobble, and $30 \%$ consists of silt/mud. In the outer bay, the east shore is rocky, as is the area around the Charity Islands. The western shore has extensive sandy areas, with rock and clay found near Point Lookout. Most of the offshore region of the outer bay has a bottom consisting of silty sand (Nalepa unpublished). 


\section{METHODS}

Locations of the sampling sites in Saginaw Bay are given in Figure 1. Larvae were collected at all sites except Stations 6, 15, and 27 at approximately monthly intervals from April to November in 1991, and from April to October in 1992 and 1993. On some dates, not all sites were sampled because of poor weather conditions; sites sampled on each date are given in Nalepa et al. (in press). Duplicate samples were collected at each site using a conical plankton net $(63-\mu \mathrm{m}$ mesh openings, $29.5 \mathrm{~cm}$ diameter, and $113 \mathrm{~cm}$ long). The net was hauled vertically from $1 \mathrm{~m}$ off the bottom to the surface; actual distance of the net haul was determined with a block/cable metering system. Net contents were narcotized with club soda before being preserved in $5 \%$ sugared formalin. In the laboratory, larvae were counted along with other zooplankton. The sample was subdivided in a Folsom plankton splitter as many times as necessary to give subsamples containing 200-300 organisms (total).

Newly-settled juveniles were estimated by counting individuals settled onto artificial substrates at an inner bay site (Station 5) and an outer bay site (Station 19) (Fig. 1). Substrates were clay tiles $(14.2 \mathrm{~cm} \times 14.2 \mathrm{~cm})$ with a smooth and grooved side. Tiles were held vertically by upright, aluminum supports that were fixed in a fiberglass tray filled with concrete. Vertical placement of the tiles prevented preferential settlement on upper surfaces as observed with horizontal placement (Marsden $e t$ al. 1993). Ten tiles were placed in each tray and positioned at right angles to each other. The entire tray was placed on the bottom (one per site), with actual location of the tiles about $28 \mathrm{~cm}$ above bottom. At approximately monthly intervals in 1991 and 1992, the trays were brought to the surface and 4-6 tiles removed. Tiles were placed separately into plastic bags and frozen. The removed tiles were replaced with new tiles that were collected the next sampling period. This procedure provided data on the number of settled juveniles over the monthly exposure period. Other tiles were left in place until the last sampling date to provide data on the total number of juveniles settled during the entire exposure period. At times, weather or technical problems prevented the collection of tiles for a given month. To compensate for differences in days of exposure, all results are reported as individuals settled per unit area per day. In 1991, trays were placed on the bottom in June and retrieved in November. In 1992 and 1993, trays were placed on the bottom in May and retrieved in October. In 1993, tiles were not collected on a monthly basis so only data on the total number settled over the entire exposure period were obtained. In the laboratory, settled mussels were removed from the tiles and counted under $12 \times$ magnification.

Density estimates of mussels on bottom substrates (here termed adults) were obtained in fall 1991, 1992, and 1993 at all sites in Figure 1 except Station 21. Depending upon the type of substrate, densities were estimated using either SCUBA divers or a surface-deployed grab sampler. At sites with a hard substrate (sand, gravel, cobble; Table 1), divers randomly placed a 0.25 or $0.5 \mathrm{~m}^{2}$ square frame on the bottom and hand-collected all hard material within the frame area (diver-quadrat method). After all material had been removed, the surface area within the frame was re-sampled using a diver-operated suction device fitted with a nitex net with $0.5-\mathrm{mm}$ openings (Winnell and Jude 1987); this procedure ensured that all loose mussels were included in the sample. Triplicate samples were collected randomly at each site with divers moving about $2-3 \mathrm{~m}$ between replicates. At sites where the bottom consisted of mostly silt, densities were estimated using a Ponar grab. Triplicate samples were washed into an elutriation device fitted with a Nitex sleeve having $0.5-\mathrm{mm}$

TABLE 1. Sampling depth and substrate type at sampling sites in inner and outer Saginaw Bay, 1991-93.

\begin{tabular}{lrl}
\hline \hline Station & Depth $(\mathrm{m})$ & \multicolumn{1}{c}{ Substrate } \\
\hline Inner bay & & \\
4 & 7.0 & Silt/mud \\
5 & 3.5 & Cobble, sand, gravel \\
6 & 4.0 & Sand, gravel, some cobble \\
7 & 7.0 & Silt/mud \\
10 & 11.0 & Silt/mud \\
11 & 9.0 & Silty sand \\
13 & 3.0 & sand, gravel, some cobble \\
14 & 3.5 & Sand, gravel, some cobble \\
15 & 3.0 & Sand, some cobble \\
16 & 3.5 & Sand, gravel, some cobble \\
Outer bay & & \\
19 & 4.0 & Cobble, some sand \\
20 & 17.0 & Fine sand, silt overlay \\
23 & 28.5 & Fine sand \\
24 & 12.5 & Fine sand, silt overlay \\
27 & 5.5 & Bedrock, some cobble \\
\hline
\end{tabular}


openings (Nalepa 1987). The residue was preserved in $5 \%$ buffered formalin.

For each sample, up to 500 mussels were counted and measured (shell length); samples with a greater number of mussels were proportionally split, counted, and measured, and the portion applied to the entire sample. For length-frequency distributions, mussels with a shell length $<5 \mathrm{~mm}$ were counted and placed into a single size category; since these mussels were separated with the naked eye or with a $2 \times$ magnifier, some smaller mussels $(0.5-1.0 \mathrm{~mm})$ were possibly missed. Mussels with a shell length $>5 \mathrm{~mm}$ were individually measured using a digitizer pad and placed into size categories of $1-\mathrm{mm}$ intervals.

To examine within-site variability in densities, additional samples were collected using the diverquadrat method in May/June 1994 at two of the sites, Stations 5 and 14. The sampling design for these collections consisted of taking samples at the established station and at locations that were 0.4 and 0.8 $\mathrm{km}$ from the established station along north, south, east, and west transects. Nine replicate samples were taken at each of the 9 locations for a total of 81 replicate samples. The nine replicates at each location were taken 2-3 $\mathrm{m}$ apart and collected in groups of three along the direction of the transect. At Station 5 and at each of three locations around this site (south $-0.8 \mathrm{~km}$, west $-0.4 \mathrm{~km}$, west $-0.8 \mathrm{~km}$ ), 3 to 10 rocks were collected in the quadrats and placed separately into plastic bags. The number of mussels attached to each rock was determined, and the exposed area of the rock estimated by pressing aluminum foil on the rock surface, and then weighing the foil. The weight of a foil piece with known surface area was used to convert foil weight to rock surface area. This method of calculating mussel densities was termed the rock-area method.

To determine the relationship between soft tissue weight and shell length, mussels were collected at one of the inner bay sites (Station 5) in November 1991 (one date) and at approximately monthly intervals from May to October in 1992 (seven dates) and in 1993 (five dates). Mussels were collected with an epibenthic sled towed behind a small boat. After collection, mussels were separated into five size categories based on relative shell length. Soft tissues of at least five individuals from each size category were removed from the shell, placed individually into combusted, preweighed aluminum planchets, dried at $60^{\circ} \mathrm{C}$ for at least $48 \mathrm{~h}$, and ashed at $550^{\circ} \mathrm{C}$ for $1 \mathrm{~h}$. Ash-free dry weight per unit shell length (AFDW:SL) was described by the general allometric equation $W=a L^{b}$, where $W$ is the AFDW of the soft tissue in $\mathrm{mg}$, and $\mathrm{L}$ is the length of the shell in $\mathrm{mm}$. Weight and length were converted to natural logs and a linear regression equation determined.

Total biomass was determined by multiplying the number of individuals in each size category by the AFDW of the median length of that category. For purposes of calculation, individuals in the $<5 \mathrm{~mm}$ category were assigned a median length of $2.5 \mathrm{~mm}$. Since both densities and length frequencies of the population were determined in the fall, only the AFDW:SL relationship for the fall (SeptemberNovember) of each year was used to determine total biomass. It was assumed that the AFDW:SL relationship was the same for all sites in the inner bay. Because of difficulties in obtaining mussels consistently with the epibenthic sled at the outer bay sites, the AFDW: SL relationship for mussels from the outer bay was not determined and biomass values are not presented.

On each date larvae were sampled, water samples were collected at the 1-m depth at each site for the determination of temperature, chlorophyll, and particulate organic carbon (POC). Exact methods of collection and laboratory analysis are given in Nalepa $e t$ al. (in press). We present data from just two of the sites, Stations 5 and 19, since these two sites typify conditions in the inner and outer bay respectively, were of similar depth and substrate type (Table 1), and were the only two sites where all life stages of Dreissena were collected. Data from other sites are summarized by Fahnenstiel et al. (1995) and Johengen et al. (1995).

\section{RESULTS}

\section{Temperature, Chlorophyll, and Carbon}

While highest mean temperatures occurred in 1991 at both inner bay (Station 5) and outer bay (Station 19) sites, temperatures at the former site were significantly higher than the latter site over the 3-year period (Table 2; paired t-test; $\mathbf{P}<0.01$ ). Yearly mean temperatures at the two sites were most similar in $1991\left(1.2^{\circ} \mathrm{C}\right.$ difference $)$ and most different in $1993\left(3.6^{\circ} \mathrm{C}\right.$ difference). Mean chlorophyll and POC declined between 1991 and 1993 at both sites (Table 2). Although mean chlorophyll concentrations were generally higher at the inner bay site, differences between the sites were not significant (paired $t$-test; $P>0.05$ ) over the 3-year period. While concentrations of POC were significantly (paired t-test; $\mathrm{P}<0.01$ ) higher at the inner 
TABLE 2. Temperature, chlorophyll, and particulate organic carbon (POC) at an inner bay (Station 5) and an outer bay (Station 19) site in Saginaw Bay in 1991-93. Dates given are when samples were collected at the two sites, respectively.

\begin{tabular}{|c|c|c|c|c|c|c|}
\hline \multirow[b]{2}{*}{ Date } & \multicolumn{2}{|c|}{ Temperature (C) } & \multicolumn{2}{|c|}{ Chlorophyll $(\mu \mathrm{g} / \mathrm{L})$} & \multicolumn{2}{|c|}{$\mathrm{POC}(\mathrm{mg} / \mathrm{L})$} \\
\hline & St. 5 & St. 19 & St. 5 & St. 19 & St. 5 & St. 19 \\
\hline \multicolumn{7}{|l|}{ Year:1991 } \\
\hline 2,3 May & 10.9 & 8.0 & 15.9 & 11.4 & 1.7 & 1.1 \\
\hline 21,20 May & 20.2 & 14.4 & 4.4 & 15.1 & 1.0 & 1.4 \\
\hline 18,17 June & 23.0 & 21.9 & 8.6 & 5.2 & 1.5 & 0.8 \\
\hline 26,23 July & 23.4 & 25.7 & 9.1 & 3.4 & 2.3 & 0.6 \\
\hline 22,21 August & 23.6 & 21.8 & 2.6 & 3.0 & 1.2 & 0.7 \\
\hline 9,12 September & 23.5 & 21.0 & 2.6 & 4.8 & 1.1 & 0.9 \\
\hline 7,16 October & 12.0 & 11.0 & 1.7 & 2.6 & 0.7 & 0.4 \\
\hline 8,12 November & 2.3 & 5.7 & 2.1 & 1.1 & 0.6 & 0.3 \\
\hline mean & 17.4 & 16.2 & 5.9 & 5.8 & 1.3 & 0.8 \\
\hline \multicolumn{7}{|l|}{ Year:1992 } \\
\hline 15 April & 4.5 & 4.2 & 3.8 & 1.2 & 0.8 & 0.2 \\
\hline 6 May & 10.8 & 5.5 & 1.3 & 2.7 & 0.4 & 0.4 \\
\hline 27,29 May & 15.1 & 14.5 & 0.4 & 0.1 & - & 1.3 \\
\hline 15,16 June & 19.9 & 17.3 & 2.1 & 0.5 & 1.1 & 0.5 \\
\hline 21,20 July & 20.2 & 20.5 & 7.8 & 3.2 & 1.2 & 0.7 \\
\hline 10,11 August & 23.8 & 20.1 & 11.9 & 1.3 & 2.8 & 0.4 \\
\hline 9,14 September & 18.6 & 18.9 & 16.4 & 2.7 & 3.3 & 0.9 \\
\hline 5,7 October & - & 14.3 & 2.9 & 1.9 & 0.8 & 0.6 \\
\hline mean & 16.1 & 14.4 & 5.8 & 1.7 & 1.5 & 0.6 \\
\hline \multicolumn{7}{|l|}{ Year:1993 } \\
\hline 2,3 May & 9.5 & 6.2 & 0.8 & 0.4 & 0.4 & 0.2 \\
\hline 21,20 May & 14.2 & 11.2 & 2.1 & 0.1 & 0.1 & - \\
\hline 18,17 June & 20.0 & 18.2 & 1.0 & 0.4 & 0.2 & 0.1 \\
\hline 26,23 July & 24.2 & 21.8 & 1.1 & 3.2 & 0.4 & 0.6 \\
\hline 22,21 August & 21.4 & 20.6 & 2.6 & 2.4 & 0.8 & 0.6 \\
\hline 9,12 September & 19.4 & 18.6 & 2.9 & 4.3 & 0.8 & 0.9 \\
\hline 7,16 October & 11.7 & 12.4 & 2.7 & 1.8 & 0.6 & 0.4 \\
\hline mean & 17.2 & 13.6 & 1.9 & 1.6 & 0.5 & 0.5 \\
\hline
\end{tabular}

bay site over all sampling dates, greatest differences occurred in 1991 and 1992; by 1993, mean POC at the two sites was similar.

\section{Density of Larvae and Newly-Settled Juveniles}

Over all sites, larvae were not found until June in 1991, but as early as the first week in May in 1992 and late May in 1993 (Table 3). Peak densities occurred in either July or August of each year. In the inner bay, larval densities increased between 1991 and 1993. For the June-September period (period of greatest abundance), there was a significant difference between years, with densities significantly higher in 1993 than in 1991 (ANOVA; P <.05;
Tukeys HSD comparison test). For the outer bay, yearly differences were not detected (ANOVA; $P>0.05$ ). Although mean larval densities tended to be higher in the inner bay than in the outer bay on any given sampling date, overall density within the two regions was not significantly different over the 3 -year period (ANOVA, P > 0.05; all sites pooled), and more specifically, significant differences between Stations 5 and 19, were not detected (paired t-test; $\mathrm{P}>0.05$ ). When densities in the two regions were compared year by year, densities were significantly higher ( $t$-test; $P<0.05$ ) in the inner bay in 1993. Distributions of larvae were generally very patchy (Fig. 2). Densities were frequently (5 of 12 sampling dates) highest in the southwestern portion 
TABLE 3. Mean density (per $\mathrm{m}^{3}$ ) of Dreissena larvae in the inner and outer bay on each sampling date in 1991-93. Values derived from densities at Stations 4 through 16 in the inner bay $(n=8)$ and Stations 19 through 24 in the outer bay $(n=5)$. In parenthesis is the density of larvae specifically at Station 5 in the inner bay and Station 19 in the outer bay.

\begin{tabular}{|c|c|c|c|c|c|c|c|}
\hline \multirow[b]{2}{*}{ Year } & \multicolumn{7}{|c|}{ Month } \\
\hline & Early May & Late May & June & July & August & September & October \\
\hline \multicolumn{8}{|l|}{ Inner Bay } \\
\hline 1991 & $\begin{array}{c}0 \\
(0)\end{array}$ & $\begin{array}{c}0 \\
(0)\end{array}$ & $\begin{array}{c}81 \pm 81 \\
(0)\end{array}$ & $\begin{array}{c}470 \pm 107 \\
(541)\end{array}$ & $\begin{array}{c}1,705 \pm 889 \\
(2,340)\end{array}$ & $\begin{array}{c}1,604 \pm 1,086 \\
(263)\end{array}$ & $\begin{array}{c}177 \pm 135 \\
(51)\end{array}$ \\
\hline 1992 & $\begin{array}{c}343 \pm 343 \\
(0)\end{array}$ & $\begin{array}{c}495 \pm 343 \\
(2,575)\end{array}$ & $\begin{array}{c}4,608 \pm 2,905 \\
\text { (0) }\end{array}$ & $\begin{array}{c}5,428 \pm 1,173 \\
(3,909)\end{array}$ & $\begin{array}{c}1,399 \pm 547 \\
(3,130)\end{array}$ & $\begin{array}{c}1,002 \pm 814 \\
(0)\end{array}$ & $\begin{array}{c}0 \\
(0)\end{array}$ \\
\hline 1993 & $\begin{array}{c}0 \\
(0)\end{array}$ & $\begin{array}{c}35 \pm 35 \\
(0)\end{array}$ & $\begin{array}{c}3,647 \pm 944 \\
(3,789)\end{array}$ & $\begin{array}{c}10,874 \pm 4,918 \\
(33,334)\end{array}$ & $\begin{array}{c}6,172 \pm 2,852 \\
(5,337)\end{array}$ & $\begin{array}{c}1,068 \pm 883 \\
(0)\end{array}$ & $\begin{array}{c}172 \pm 149 \\
(70)\end{array}$ \\
\hline \multicolumn{8}{|l|}{ Outer Bay } \\
\hline 1991 & $\begin{array}{c}0 \\
(0)\end{array}$ & $\begin{array}{c}0 \\
(0)\end{array}$ & $\begin{array}{c}524 \pm 308 \\
(0)\end{array}$ & $\begin{array}{c}549 \pm 389 \\
(2,028)\end{array}$ & $\begin{array}{c}1,682 \pm 1,410 \\
(7,556)\end{array}$ & $\begin{array}{c}0 \\
(0)\end{array}$ & $\begin{array}{c}0 \\
(0)\end{array}$ \\
\hline 1992 & $\begin{array}{c}1 \pm 1 \\
(0)\end{array}$ & $\begin{array}{c}37 \pm 37 \\
(182)\end{array}$ & $\begin{array}{c}0 \\
(0)\end{array}$ & $\begin{array}{c}2,222 \pm 1,252 \\
(6,683)\end{array}$ & $\begin{array}{c}10,004 \pm 8,368 \\
(3,485)\end{array}$ & $\begin{array}{c}505 \pm 367 \\
(541)\end{array}$ & $\begin{array}{c}4 \pm 4 \\
(0)\end{array}$ \\
\hline 1993 & $\begin{array}{l}- \\
(-)\end{array}$ & $\begin{array}{c}0 \\
(0)\end{array}$ & $\begin{array}{c}210 \pm 210 \\
(1,053)\end{array}$ & $\begin{array}{c}453 \pm 286 \\
(409)\end{array}$ & $\begin{array}{c}291 \pm 59 \\
(310)\end{array}$ & $\begin{array}{c}120 \pm 64 \\
(327)\end{array}$ & $\begin{array}{c}3 \pm 3 \\
(14)\end{array}$ \\
\hline
\end{tabular}

of the inner bay, and on only one sampling date (July 1992) were densities generally similar throughout the entire bay.

The period of settling and the total number of newly-settled juveniles varied greatly between years (Table 4). At the inner bay site (Station 5), two peaks were evident in 1991. The first peak occurred in June-July and a second, greater peak occurred in August-October. The second peak coincided with the higher number of larvae found in the water column at that time. In 1992, an early peak occurred in May-July, but a second, late summer/fall peak was not observed. Thus, while densities of larvae in late summer/fall were similar in 1991 and 1992, juvenile settlement during this period occurred in the former year and not the latter. Although data at the outer bay site (Station 19) were limited, strong seasonal peaks were not apparent in 1991, and in 1992 settlement occurred mainly in June-July. Yearly trends in the total number of newly-settled juveniles were similar at the two sites. Total number was highest in 1991 , declined dramatically in 1992, and then increased in 1993 (Table 4). This yearly trend did not parallel trends in the number of larvae in the water column since, as noted, larval densities increased between 1991 and 1993.

Theoretically, over a season, the total number of juveniles settled onto tiles that were kept in place for the entire exposure period should equal the sum of the number settled onto tiles that were removed each month. However, differences in the two density estimates did occur, and differences were not consistent between years. At Station 5, total densities of juveniles settled onto tiles in place for the entire period were $248,000 / \mathrm{m}^{2}$ and $3,600 / \mathrm{m}^{2}$ in 1991 and 1992, respectively, while total densities derived from summing the density on tiles removed each month were $145,700 / \mathrm{m}^{2}$ and $11,000 / \mathrm{m}^{2}$, respectively.

\section{Density and Biomass of Adults}

Mean densities of adult mussels at sites with hard substrate differed over the 3 years, with densities in 1992 significantly higher than in 1991 or 1993 (Table 5; ANOVA, Tukey HSD, $\mathrm{P}<0.05$ ). Mean overall densities were $11,700,33,200$, and $4,100 / \mathrm{m}^{2}$ in 1991, 1992, and 1993, respectively. Yearly trends at individual sites were highly variable. For example, densities at four sites peaked in 1992 then decreased in 1993 (Stations 5, 14, 16, and 19), densities at one site peaked in 1991 and then declined in 1992 (Station 15), and densities at three sites were generally consistent all three years (Stations 6, 13, and 27). Densities in the inner and outer bay were not significantly different (ANOVA, $P>0.05$ ). Yearly trends in biomass reflected observed trends in density; mean biomass at all inner 

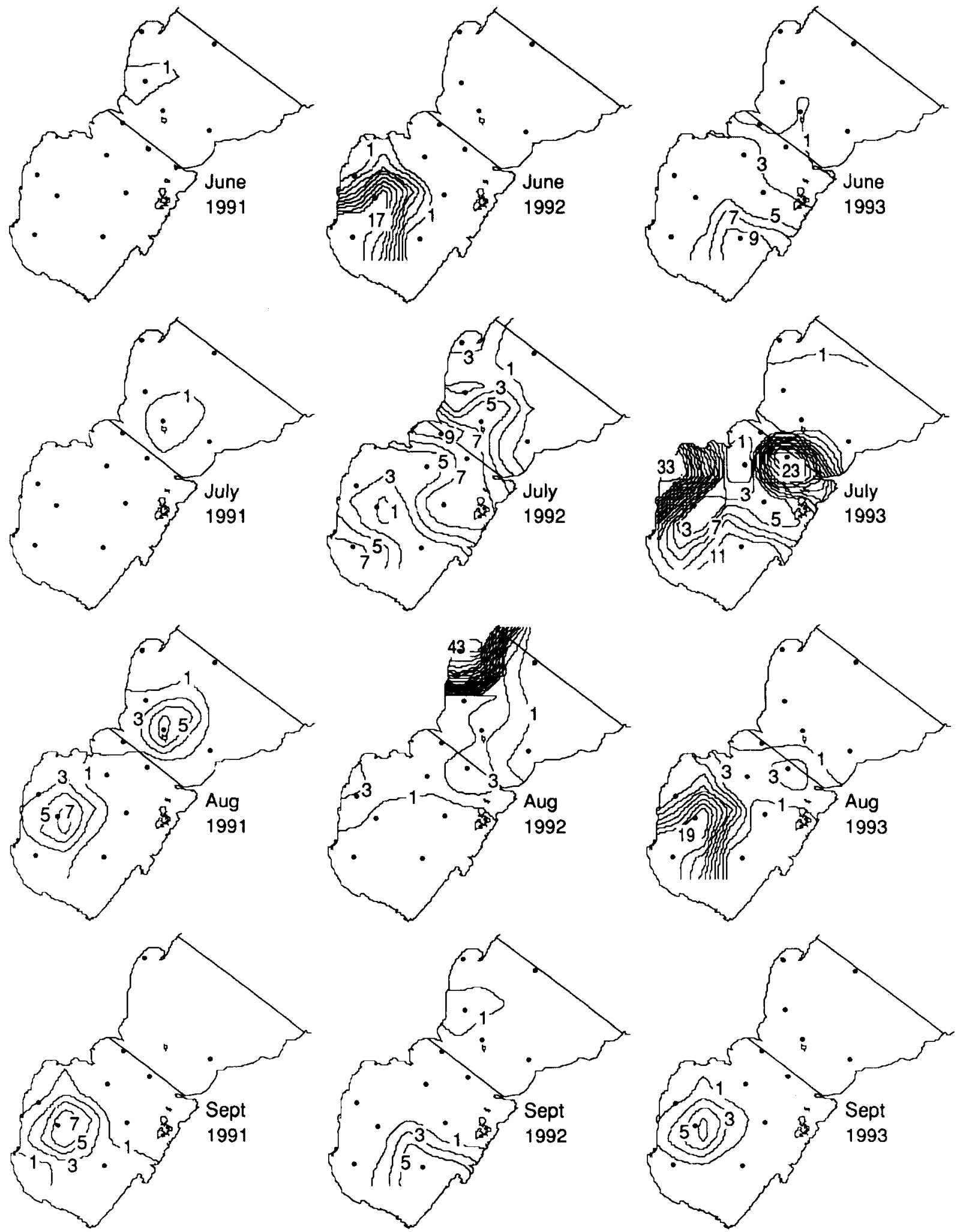

FIG. 2. Isopleth distribution of Dreissena larvae at the 1-m depth in Saginaw Bay in June, July, August, and September in 1991-1993. Values given are per $m^{3} \times 10^{-3}$. Station location denoted by (॰). 
TABLE 4. Monthly and total number of zebra mussels settled onto artificial substrates (clay tiles) placed in the inner bay (Station 5) and outer bay (Station 19). Monthly values are given as mean ( + SE) number settled (per $m^{2}$ per day) for the period between retrievals, while total values are mean $( \pm S E)$ number settled (per $\mathrm{m}^{2}$ ) over the entire time period (days of exposure given in parentheses). The source of variation is the number on individual tiles (4 per monthly value; 2-12 for total values). Monthly means were not obtained in 1993.

\begin{tabular}{|c|c|c|c|c|c|c|c|}
\hline & June & July & August & September & October & November & Total \\
\hline \multicolumn{8}{|l|}{ Year:1991 } \\
\hline Station 5 & - & $974 \pm 473$ & $154 \pm 24$ & $2,127 \pm 366$ & $1,602 \pm 347$ & - & $247,940 \pm 29,480(110)$ \\
\hline Station 19 & - & $89 \pm 42$ & $77 \pm 26$ & $54 \pm 18$ & - & 一 & - \\
\hline \multicolumn{8}{|l|}{ Year:1992 } \\
\hline Station 5 & $257 \pm 245$ & $100 \pm 40$ & - & $4 \pm 1$ & - & $1 \pm 1$ & $3,560 \pm 650(162)$ \\
\hline Station 19 & $<1$ & $115 \pm 75$ & - & $12 \pm 4$ & - & $2 \pm 1$ & $1,330 \pm 330(166)$ \\
\hline \multicolumn{8}{|l|}{ Year:1993 } \\
\hline Station 5 & & & & & & & $114,220 \pm 10,030(176)$ \\
\hline Station 19 & & & & & & & $97,050 \pm 8,700(150)$ \\
\hline
\end{tabular}

TABLE 5. Mean densities ( $\pm S E$; per $m^{2}$ ) and biomass ( $g$ AFDW soft tissue; in parentheses) of adult Dreissena at inner an outer bay sites in Saginaw Bay with hard substrates. Samples were taken in fall of each year except in 1994 when samples were taken in spring (May/June). Samples were collected by the diver-quadrat method; three replicates were taken per site except in 1994 when nine replicates were taken.

\begin{tabular}{ccccc}
\hline \hline & & & & \\
Station & 1991 & 1992 & 1993 & 1994 \\
\cline { 2 - 5 } Inner Bay & & & & \\
5 & $28,244 \pm 2,457$ & $75,296 \pm 29,280$ & $237 \pm 48$ & $4,099 \pm 454$ \\
& $(10.5)$ & $(106.9)$ & $(0.2)$ & \\
6 & $4,453 \pm 1,387$ & $3,620 \pm 2,444$ & $3,557 \pm 1,616$ & \\
& $(4.4)$ & $(8.9)$ & $(6.7)$ & \\
13 & & $8,956 \pm 6,720$ & $376 \pm 60$ & \\
& $208 \pm 115$ & $63,242 \pm 18,999$ & $7,506 \pm 3,459$ & $838 \pm 95$ \\
14 & $(0.1)$ & $(144.0)$ & $(11.6)$ & \\
15 & $43,117 \pm 1,050$ & $5,556 \pm 2,492$ & $7,341 \pm 2,828$ & \\
& $(34.1)$ & $(8.6)$ & $(3.4)$ & \\
16 & $26 \pm 26$ & $46,360 \pm 7,728$ & $4,830 \pm 1,768$ & \\
& $(<0.1)$ & $(78.3)$ & $(4.4)$ & \\
Mean & 10,130 & 33,838 & 3,975 & \\
& $(9.8)$ & $(61.9)$ & $(4.5)$ & \\
Outer Bay & & & & \\
19 & $2,480 \pm 1,219$ & $57,640 \pm 1,219$ & $3,328 \pm 900$ & \\
27 & $3,408 \pm 2,772$ & $4,695 \pm 2,542$ & $5,813 \pm 2,383$ & \\
Mean & 2,944 & 31,168 & 4,571 & \\
\hline
\end{tabular}


bay sites with hard substrates was $9.8,61.9,4.5$ $\mathrm{g} / \mathrm{m}^{2}$ in each of the three years, respectively (Table 5). For sites with soft substrate, densities were generally low throughout the 3-year sampling period, except at Station 11 in the inner bay where densities increased dramatically in 1993 (Table 6).

To further examine the decline in densities between 1992 and 1993 at many of the sites, densities in spring 1994 were compared to fall 1992 and 1993 at two of the sites with hard substrates where densities declined in 1993 (Stations 5 and 14). Since most recruitment occurs in the summer, it was assumed that values in spring would not differ greatly from values the previous fall. Densities in spring 1994 at these two sites were not significantly different from those in fall 1993, but were significantly lower than densities in 1992 (Table 5; ANOVA, Tukey HSD, $\mathrm{P}<0.05$ ). This finding further verifies declines in density observed between 1992 and 1993.

As noted, the primary purpose of the spring 1994 survey was to examine small-scale patchiness in densities at two of the sites with hard substrates, Stations 5 and 14. Density estimates at the eight

TABLE 6. Mean densities ( $\pm S E$; per $m^{2}$ ) and biomass ( $\mathrm{g}$ AFDW soft tissue; in parentheses) of adult Dreissena at inner an outer bay sites in Saginaw Bay with soft substrates. Samples were taken in fall of each year, three replicates per site with a Ponar grab.

\begin{tabular}{|c|c|c|c|}
\hline \multirow[b]{2}{*}{ Station } & \multicolumn{3}{|c|}{ Year } \\
\hline & 1991 & 1992 & 1993 \\
\hline \multicolumn{4}{|c|}{ Inner Bay } \\
\hline 4 & $\begin{array}{c}22 \pm 13 \\
(<0.1)\end{array}$ & 0 & $\begin{array}{c}22 \pm 13 \\
(<0.1)\end{array}$ \\
\hline 7 & 0 & $\begin{array}{l}30 \pm 19 \\
(<0.1)\end{array}$ & $\begin{array}{l}98 \pm 19 \\
(<0.1)\end{array}$ \\
\hline 10 & $\begin{array}{l}15 \pm 7 \\
(<0.1)\end{array}$ & 0 & 0 \\
\hline 11 & 0 & $\begin{array}{c}143 \pm 79 \\
(<0.1)\end{array}$ & $\begin{array}{c}3,018 \pm 2,916 \\
(2.9)\end{array}$ \\
\hline Mean & $\begin{array}{c}9 \\
(<0.1)\end{array}$ & $\begin{array}{c}43 \\
(<0.1)\end{array}$ & $\begin{array}{c}785 \\
(0.7)\end{array}$ \\
\hline \multicolumn{4}{|c|}{ Outer Bay } \\
\hline 20 & 0 & $7 \pm 7$ & $22 \pm 22$ \\
\hline 23 & 0 & 0 & 0 \\
\hline 24 & 0 & 0 & 0 \\
\hline Mean & 0 & 2 & 7 \\
\hline
\end{tabular}

sampling locations in the immediate area (within $1.6 \mathrm{~km}$ ) of each site and at the site itself varied from 410 to $7,690 / \mathrm{m}^{2}$ at Station 5 and from 840 to $4,760 / \mathrm{m}^{2}$ at Station 14 (Table 7). Coefficients of variation of the mean densities at the nine sampling locations were $64 \%$ and $63 \%$ at the two sites, respectively. In comparison, the coefficient of variation for the means for all eight sites with a hard substrate sampled in fall 1993 was $66 \%$. Thus, by fall 1993/spring 1994, variation within $1.6 \mathrm{~km}$ of a given site was similar to that found between all hard-substrate sites throughout the entire bay. Further, the coefficient of variation of annual means for 1991-94 was 128 and $169 \%$ at Stations 5 and 14, respectively, so variation at each of these two sites in spring 1994 was considerably less than the variability at each site between years.

For samples collected at Station 5 in spring 1994, densities estimated using the diver-quadrat method averaged 12 times lower than densities estimated using the rock-area method (Table 7).

\section{Length Frequency}

In fall 1991, the adult population of Dreissena in both the inner and outer bay consisted mostly of small individuals that had been recruited that year (Fig. 3). At the six sites in the inner bay with hard substrate, $66 \%$ (range $52-86 \%$ ) of the population had a shell length of $<5 \mathrm{~mm}$. At the two outer bay sites with hard substrate, Stations 19 and 27, 86\% and $88 \%$ of the population had a shell length $<5$ $\mathrm{mm}$. While length-frequency distributions showed that the 1991-cohort accounted for most of the population in 1991, there were larger individuals $(>15$ $\mathrm{mm}$ ) present at most of the sites. These large individuals likely represented either the 1989- or 1990cohort. Densities of this second cohort were low at all sites except at Station 15 (Fig. 3). The lengthfrequency distribution at this site clearly showed two modal peaks (one at $<5 \mathrm{~mm}$ and another at 18 $\mathrm{mm}$ ) suggesting that the larger-sized cohort was likely the 1990 year class. After 1991, length-frequency distributions varied considerably between sites, mainly as related to differences in growth rate of the 1991-cohort. In fall 1992, modal lengths of the 1991-cohort varied from 7-9 mm (Station 5) to 12-13 mm (Station 13) in the inner bay, and from 8-9 $\mathrm{mm}$ (Station 19) to $15 \mathrm{~mm}$ (Station 27) in the outer bay. Also, the 1990-cohort, which showed rapid growth to $18 \mathrm{~mm}$ after 1 year, was no longer distinguishable in the population after 2 years (see Station 15; Fig. 3). Similarly, the 1991-cohort could 
TABLE 7. Mean densities $\left( \pm S E\right.$; per $\left.m^{2}\right)$ at each of the sites sampled in spring 1994. Sites were located on transects (north, south, east, west) at $0.4 \mathrm{~km}$ and at $0.8 \mathrm{~km}$ from the station location. Nine replicates were collected at each site. At Station 5, 3-10 rocks were collected from four of the sites and densities were estimated using the rock-area method. See text for explanation.

\begin{tabular}{|c|c|c|c|}
\hline \multirow[b]{2}{*}{ Site } & \multicolumn{2}{|c|}{ Station 5} & \multirow{2}{*}{$\frac{\text { Station } 14}{\text { Diver-quadrat }}$} \\
\hline & Diver-quadrat & Rock-area & \\
\hline Station & $4,098 \pm 545$ & $51,530 \pm 8,367$ & $838 \pm 95$ \\
\hline North $(0.4)$ & $3,539 \pm 1,067$ & & $1,015 \pm 142$ \\
\hline North $(0.8)$ & $2,593 \pm 573$ & & $2,561 \pm 225$ \\
\hline East $1(0.4)$ & $3,172 \pm 668$ & & $863 \pm 152$ \\
\hline East $2(0.8)$ & $1,320 \pm 166$ & & $3,399 \pm 699$ \\
\hline South $(0.4)$ & $409 \pm 167$ & & $2,165 \pm 200$ \\
\hline South $(0.8)$ & $2,235 \pm 482$ & $48,320 \pm 10,866$ & $1,826 \pm 265$ \\
\hline West $(0.4)$ & $7,691 \pm 651$ & $59,634 \pm 18,954$ & $1,445 \pm 136$ \\
\hline West $(0.8)$ & $4,411 \pm 725$ & $67,188 \pm 9,385$ & $4,764 \pm 525$ \\
\hline
\end{tabular}

no longer be readily distinguished after 2 years at most of the inner bay sites. At sites where the 1991cohort still appeared to be present (see Station 5 in spring 1994 and Stations 6 and 13 in fall 1993), modal length was only $15 \mathrm{~mm}$. In contrast, the 1991-cohort was still distinguishable at the outer bay sites after 2 years, reaching a modal length of $17 \mathrm{~mm}$ at Station 19 and $>20 \mathrm{~mm}$ at Station 27 in 1993 (Fig. 3).

At each of the sites, the proportion of the total population $<5 \mathrm{~mm}$ was always less than $13 \%$ in both 1992 and 1993, indicating recruitment into the adult population was relatively low in these years compared to 1991 . This finding concurs with the low number of settled juveniles on tile substrates in 1992 , but contrasts with the relatively high number in 1993.

\section{Length-Weight}

To illustrate seasonal and yearly trends in the AFDW:SL relationship, a length-weight regression equation was calculated (regression significant on each date; $P<0.05$ ) and then used to determine temporal trends in the AFDW of a standard mussel 15-mm in shell length. This shell length represents the size at which mussel growth and survival diminished in the inner bay. In 1992, AFDW of a standard mussel was highest on the first sampling date in early May and gradually declined to a minimum in the late summer/fall. In 1993, AFDW was generally similar from May until early August before declining (Fig. 4). The overall decline in AFDW from late May until October was $62 \%$ in 1992 , but only $48 \%$ in 1993 . This difference was mainly related to a lower weight in spring 1993 compared to spring 1992; in late May 1992 a standard mussel weighed $12.0 \mathrm{mg}$ compared to only $5.9 \mathrm{mg}$ in late May 1993 . AFDW of a standard mussel declined in the fall of each successive year; weights in October/November were $8.6,4.6$, and $3.1 \mathrm{mg}$ in 1991, 1992, and 1993, respectively. The mean AFDW:DW ratio of the soft tissue was 0.84 and ranged from 0.77 to 0.88 for a given sampling date. Consistent temporal trends in the ratio were not apparent.

\section{DISCUSSION}

On a yearly basis, there was no observed relation between densities of larvae, settled juveniles, and adult Dreissena. In 1991, the first year Dreissena became widespread and abundant in Saginaw Bay, densities of larvae were the lowest of the 3-year study period, yet the number of settled juveniles was the highest, indicating high survival of larvae to the settling stage. In 1992, larval densities increased over 1991, but numbers of settled juveniles were the lowest, and densities of adults were the highest over the 3-year period. Although densities of larvae and the number of settled juveniles increased in 1993, adult densities declined. These trends should be interpreted with some caution since monthly sampling for larvae is likely inadequate to fully describe temporal changes. However, the poor temporal relation between the various life stages of Dreissena in Saginaw Bay generally 

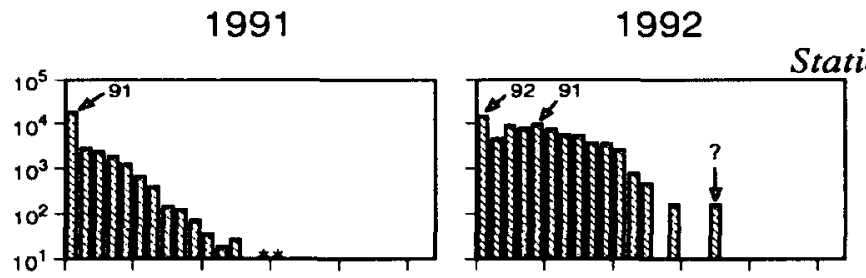

1993

1994
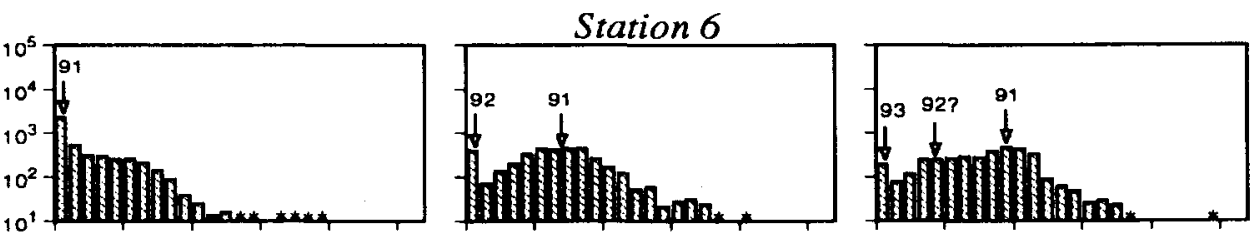

Station 13
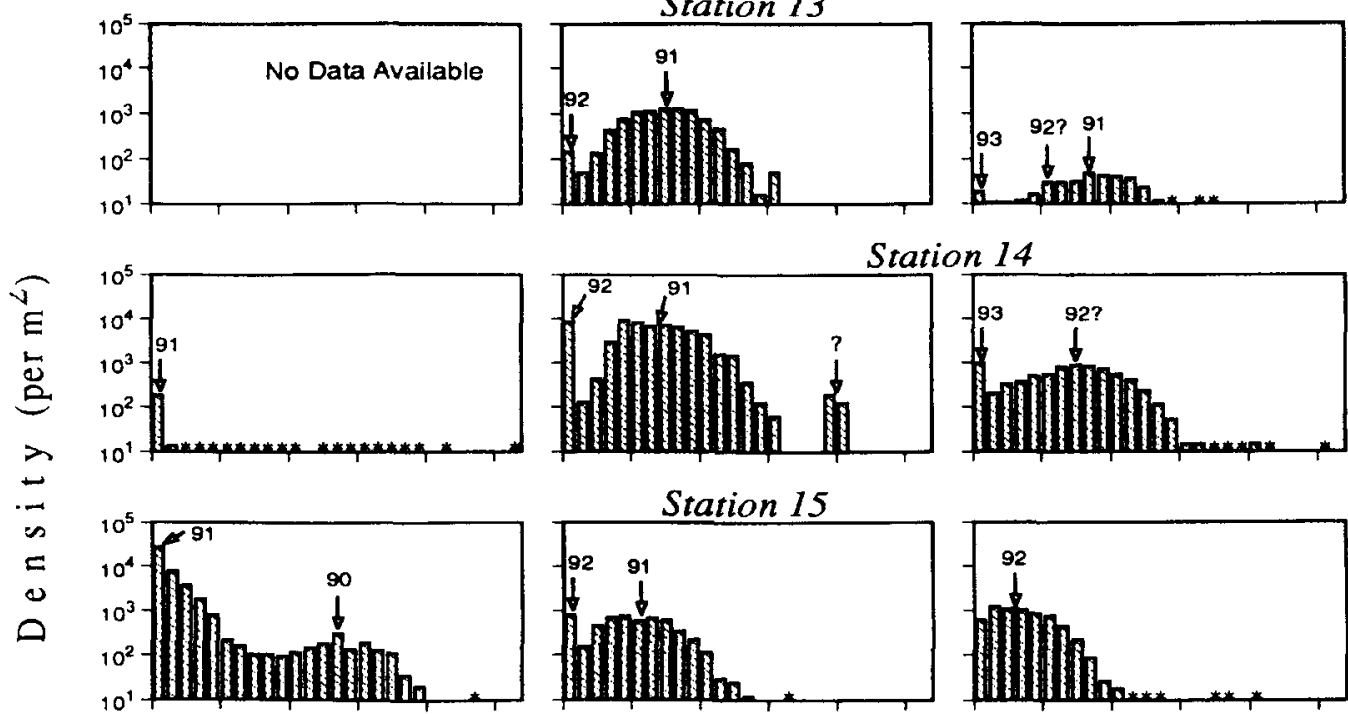

Station 14
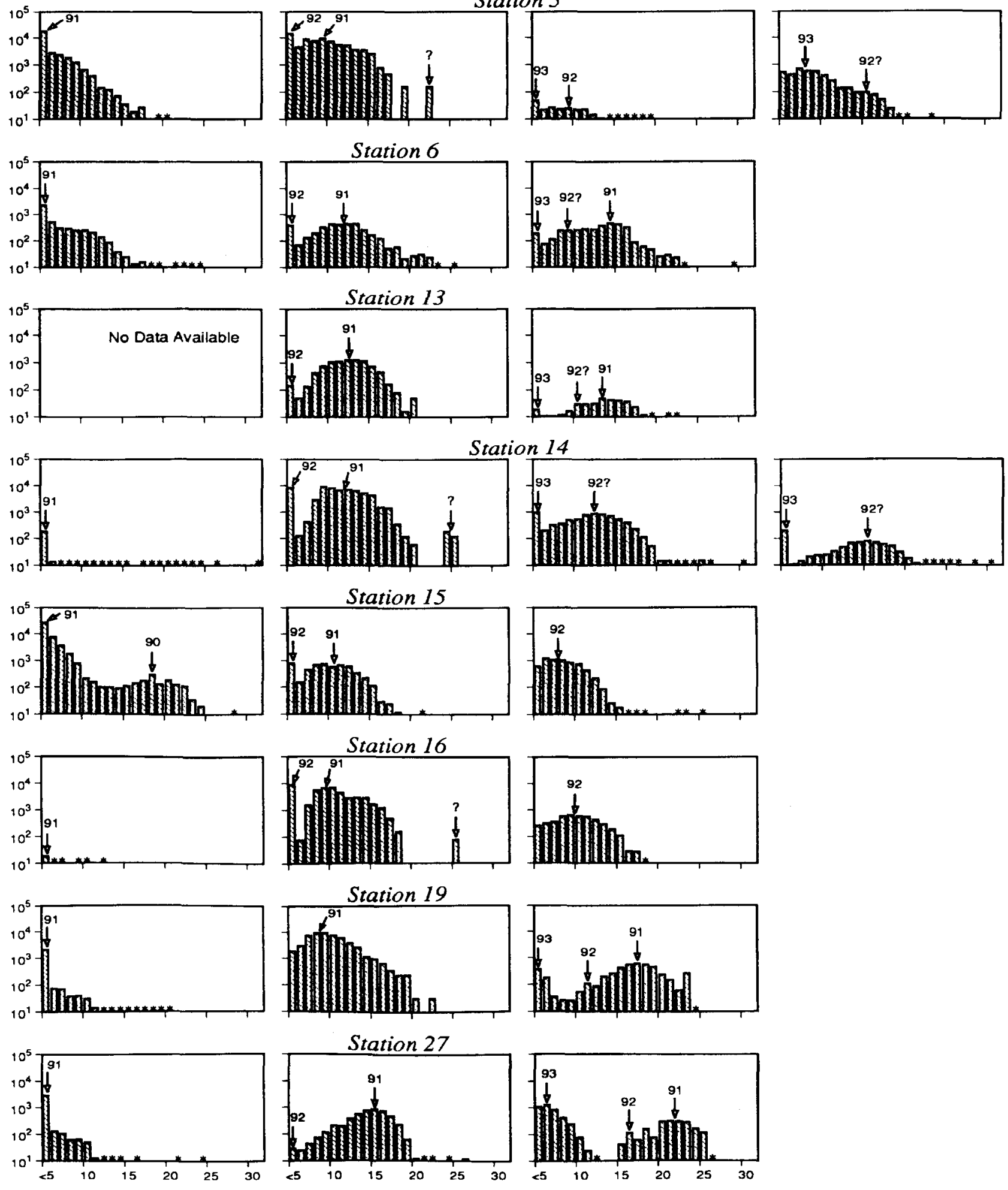

She I l L e gth $(\mathrm{m} \mathrm{m})$

FIG. 3. Length frequency distributions of adult Dreissena at sites with hard substrates in Saginaw Bay in fall 1991-93 and spring 1994. An asterisk denotes densities $\leq 100 / \mathrm{m}^{2}$. 


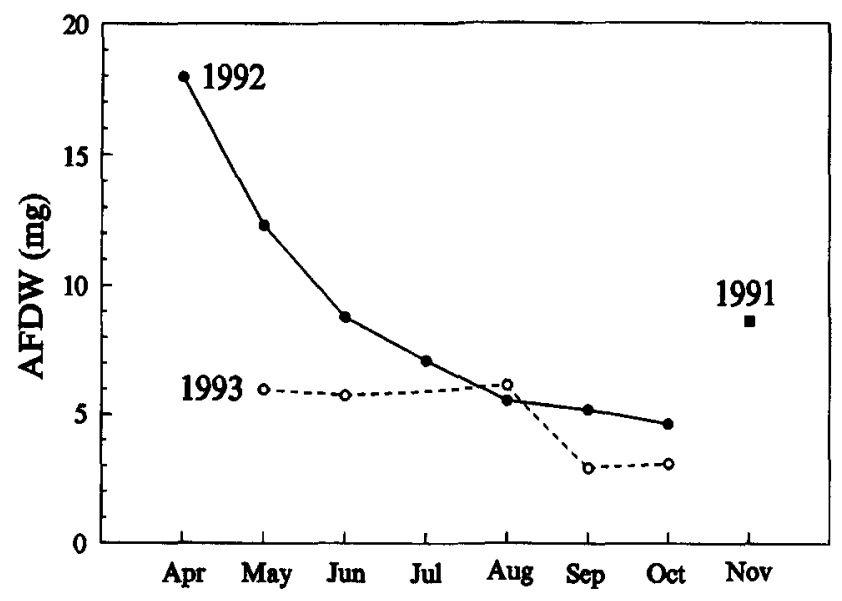

FIG. 4. Seasonal and annual trends in the ashfree dry weight of a standard $15-\mathrm{mm}$ (shell length) Dreissena from an inner Saginaw Bay site (Station 5). Weights were derived from separate length-weight regressions on each sampling date.

agrees with results reported from other Great Lakes regions during the inital years of colonization. In both western Lake Erie (Garton and Haag 1993) and southwestern Lake Michigan (Marsden et al. 1993), high numbers of settled juveniles and an increase in adult densities in one year was followed by an increase in larvae but a dramatic decline in juveniles the following year. High mortality at the settling stage after adults become established can be a result of either inadequate food (Sprung 1989), adult filtering activities (MacIsaac et al. 1991), or lack of suitable substrates (Stanczykowska and Lewandowski 1993, Sprung 1989). In Saginaw Bay, the influence of these latter two factors seemed apparent in 1993 when relatively high densities of larvae in the water column and newly-settled juveniles on tiles did not result in an increase in individuals found on bottom substrates. Poor correlation between yearly trends in densities on tiles and densities on bottom substrates may partly be attributable to differing ability to distinguish the small $(<1.0$ $\mathrm{mm}$ ) settled juveniles; these small individuals were easier to detect on the tiles than on bottom substrates. Because of growth patterns, high numbers of settled juveniles in 1991 would have led to high adult densities in 1992, and low numbers in 1992 would have led to low adult densities in 1993. However, high numbers of settled juveniles in 1993 did not lead to higher adult densities in spring 1994.
On a spatial scale, physical forces such as currents and wind-driven circulation patterns also have an influence on larval survival and recruitment into the adult population. Although differences in larval densities at inner and outer bay sites were not significant over the study period, densities tended to be higher at sites in the southwestern portion of the bay (Stations 4 and 7). Due to current patterns, particulates tend to accumulate in this region, and sedimentation rates are the highest in the bay (Robbins 1980). The same physical processes that focus particulates would also focus planktonic larvae. On the other hand, since adults can remove larvae by their filtering activities (MacIsaac et al. 1991), it can be argued that larvae were more abundant at these sites because adult densities were minimal.

Even given density-dependent and physical forces influencing recruitment, there were some inconsistencies in abundances of the life stages that are not easily explained. For instance, in 1991 the number of larvae in the water column appeared too low to result in the high number of settled juveniles observed. If the mean number of larvae throughout the water column observed at Station 5 had matured in 5-16 days (Sprung 1993) over the time period the tiles were in place, the density of settled juveniles would have ranged from $19,000 / \mathrm{m}^{2}$ to $61,000 / \mathrm{m}^{2}$. The density of settled juveniles on tiles at this station was $248,000 / \mathrm{m}^{2}$. In 1992 and 1993, the number of larvae potentially reaching the settling stage was higher than the actual number of juveniles settled onto the tiles as might be expected. Conceivably, some focusing on the tiles may have occurred in 1991, or a larval peak may have been missed.

For various reasons, it is difficult to compare densities of Dreissena found in Saginaw Bay to densities found on bottom substrates in other areas of the Great Lakes. Timing of the sampling event relative to the initial colonization, time of year samples are collected, method of collection, and the proportion of suitable substrate in a given area are all factors that can affect density estimates. Densities associated with the initial invasion period on hard substrates in Saginaw Bay appear to have peaked in 1992, or one year after the first large recruitment in 1991. Maximum density in 1992 at an individual site was $75,300 / \mathrm{m}^{2}$, and the mean density at all sites was $33,200 / \mathrm{m}^{2}$. By 1993 , mean density had declined to $4,200 / \mathrm{m}^{2}$. In comparison, densities reported from reef sites in western Lake Erie in fall 1990, or 2 years after the first large recruitment, ranged from $15,000 / \mathrm{m}^{2}$ (Garton and 
Haag 1993) to over $200,000 / \mathrm{m}^{2}$ (Leach 1993). Also in fall 1990, Dermott et al.(1993) reported densities of $54,000 / \mathrm{m}^{2}$ at a rocky nearshore site in northeastern Lake Erie. Stewart and Haynes (1994) reported fall densities of $34,000 / \mathrm{m}^{2}$ at a reef site in Lake Ontario 2 years after the initial colonization, while in nearshore areas of southwestern Lake Michigan, densities of $57,000-268,000 / \mathrm{m}^{2}$ were reported 1 year after the initial large recruitment (Marsden $e t$ al. 1993). The higher density estimates of Leach (1993) and Marsden et al. (1993) may be more related to their method of determining densities since they both used the rock-area method. As shown (Table 7), this method likely overestimates densities per unit area of bottom if not all substrate is suitable for colonization.

At sites with hard substrates in Saginaw Bay, only a limited area of the bottom might be considered suitable for mussel colonization. That is, while some druses were observed on sand, most of the mussels were found on cobble, and cobble only accounted for $5-50 \%$ of the bottom area (diver estimates) at inner bay sites and at Station 19 in the outer bay. The only site where the bottom was entirely hard was Station 27 , and colonization even at this site was not $100 \%$. Thus, the somewhat lower densities in Saginaw Bay compared to reef sites in other Great Lakes areas may simply be a function of the amount of suitable substrate. Even so, density estimates in Saginaw Bay in 1993 are within the range of $500-10,000 / \mathrm{m}^{2}$ found on similar sized substrates in other lakes (Mellina and Rasmussen 1994). Although Dreissena has been found on soft sediments in both Lake Erie and in Lake St. Clair (Hunter and Bailey 1992, Dermott and Munawar 1993, Nalepa and Schloesser 1993, Nalepa unpublished), few mussels were found at sites in Saginaw Bay with a substrate of silt or silty sand.

At most sites with hard substrates, densities of adult mussels differed considerably from year to year. However, no individual site had densities that were consistently higher or lower than the other sites over the entire 3-year sampling period. This would indicate that density differences were likely related to the dynamics of recruitment rather than to differences in chemical/physical features of specific habitats. Densities can vary widely in a given water body particularly in the early stages of the invasion period as suitable substrates become colonized and the population expands (Stanczykowska and Lewandowski 1993). For example, densities peaked at Station 15 in 1991, but densities peaked at most other sites in 1992. The large number of individuals belonging to the 1990 -cohort at Station 15 would indicate that colonization occurred at this site earlier than at other sites within the bay. Also, some of the variation between years at a particular site was likely related to the patchiness of available substrate. While navigation systems (Loran $\mathrm{C}$ ) can provide accurate positioning, even slight variation in sampling location may lead to large differences in density estimates. As shown, a maximum 19-fold difference in density occurred within just a short distance from the site location (Table 7). Similar high variation in mussel distributions were noted at specific sites in nearshore Lake Michigan where the proportion of bottom colonized by mussels ranged from 13\% to 69\% (Marsden et al. 1993). Shifting sands during storm events in Saginaw Bay both exposed and buried colonization sites (diver observations), which likely also contributed to temporal variability. Despite these sources of variation, by fall 1993/spring 1994 densities at all the sites with hard substrates were generally similar, and variation between sites was within the range of variation that occurred within a given distance $(1.6 \mathrm{~km})$ around a specific site.

While densities in the inner and outer bay were generally comparable by fall 1993/spring 1994 , length frequency distributions were quite different. This difference can be attributed to differential growth of the 1991 cohort. Growth and survival can be inferred from length/frequency distributions only if there is little or no overlap in size between cohorts. The large, initial recruitment in 1991 allowed us to readily discern this cohort at most sites in subsequent years. Growth of the 1991-cohort was generally similar in the inner and outer bay after 1 year, with modal lengths between 9-15 mm in 1992 . These growth rates compare favorably to growth in other regions of the Great Lakes as well as to growth rates in European lakes. For instance, shell length of the $1+$ cohort was $10-11 \mathrm{~mm}$ for individuals occurring on benthic substrates in western Lake Erie and Lake St. Clair (Griffths et al. 1991), and was $15 \mathrm{~mm}$ for individuals in a nearshore region of northeastern Lake Erie (Dermott et al. 1993). In European lakes, shell lengths of 9-15 $\mathrm{mm}$ have been reported for the 1+ age group (Stanczykowska 1964; Walz 1974, 1978d; bij de Vaate 1991; Smit et al. 1992). After 2 years, growth of the 1991-cohort was quite different in the inner and outer bay. By 1993, the 1991-cohort could not be clearly distinguished from the 1992-cohort at most inner bay sites. At sites where the 1991-cohort may have been 
present, the modal length was only $15 \mathrm{~mm}$. Thus, either mussel growth in the inner bay was minimal after the first year, or the typical life span of mussels in the inner bay was less than 2 years. In contrast, the 1991 cohort was still clearly distinguishable at outer bay sites in 1993. The size of this cohort (modal length $>15 \mathrm{~mm}$ ) compares to that reported for the 2+ age group in Lake Erie, Lake St. Clair, and lakes in Europe (citations above).

Based on historical data of phytoplankton composition and concentrations of nutrients and chlorophyll (Smith et al. 1977, Bierman and Dolan 1981, Stoermer and Theriot 1985), the inner bay can be considered eutrophic and the outer bay more oligotrophic. Given these trophic differences and considering the response of Dreissena populations to differing trophic conditions in European lakes, we would have expected greater growth in the inner bay and perhaps greater densities in the outer bay at sites with similar water depth and substrate type. For example, Stanczykowska (1984) showed that shell length and soft tissue weight of Dreissena in the $2+$ age group or older was greater at sites considered more enriched within a given lake, and Sprung (1993), in comparing growth rates in two lakes, found higher growth in the lake with higher seston concentrations. In a number of Polish lakes, Lewandowski (1991) reported overall higher Dreissena densities in mesotrophic lakes than in eutrophic lakes, and Dorgelo (1993) found larger mussels in eutrophic lakes but higher densities in an oligomesotrophic lake. In the Great Lakes, growth rates were higher in the more eutrophic waters of the western basin than in the eastern basin of Lake Erie (MacIsaac 1994).

Growth in Dreissena is a function of temperature and food availability (Walz 1978a, 1978b; Smit et al. 1992), and comparisons of these two variables at typical sites in the inner bay (Station 5) and outer bay (Station 19) may provide insights into differences in growth/survival as derived from length frequency distributions. According to the growth model of Schneider (1992), under conditions of constant, maximum food availability, growth is optimal at a water temperature of about $11^{\circ} \mathrm{C}$ and declines as temperatures increase or decrease. At constant temperature, growth increases with food availability until levels reach about $80 \%$ of the maximum ingestion rate. For Dreissena, the maximum ingestion rate is realized when food concentrations reach about $2 \mathrm{mg} \mathrm{C/L}$ (Walz 1978a, 1978b). In comparing water temperatures and food concen- trations at the two Saginaw Bay sites on each date, temperatures at the inner bay site were more frequently farther-removed from the optimal growth temperature than temperatures at the outer bay site, while food concentrations, as measured by chlorophyll and POC, were at least comparable to or higher than concentrations at the outer bay site (Table 2). Since growth of the 1991 cohort was similar at the two sites through 1992, the less optimal temperature regime at the inner bay site was likely compensated by higher food concentrations. In 1993, when food concentrations in the inner bay declined, growth/survival was lower than in the outer bay.

Limited growth of Dreissena in the inner bay in 1993 is consistent with the observed decline in soft tissue weight per unit shell length. Under limiting food conditions and constant temperatures over several years in Lake Constance, Dreissena displayed a decrease in soft tissue weight while shell length remained constant (growth = zero) $($ Walz 1978b). For mollusks in general, weight loss or tissue "degrowth" occurs when food supplies are inadequate to meet the metabolic demands of the organism (Russell-Hunter 1985). To assess the relative loss of tissue weight in Dreissena at the inner bay site, the weight of a standard 15-mm mussel was compared in fall of each year. Dorgelo and Kraak (1993) considered the baseline weight of Dreissena to be the weight after spawning in fall, while Smit and Dudok van Heel (1992) considered fall the best time to make biomass comparisons between different water bodies. The weight of a standard $15-\mathrm{mm}$ mussel at the inner bay site declined $65 \%$ between fall 1991 and fall 1993. To put the decline in weight of Saginaw Bay mussels in perspective, the weight of a $15-\mathrm{mm}$ mussel from the inner bay site was compared to weights of a similar-sized mussel from other lakes (Table 8). The weight of a standard mussel from the inner bay site in 1993 was the lowest of all other lakes compared.

Walz (1978a) determined that the food concentration (in $\mathrm{mg} \mathrm{C} / \mathrm{L}$ ) required to maintain body weight (growth $=$ zero) in Dreissena increased with mussel size and temperature. From his laboratory-derived relationship, a mussel with a soft tissue weight of between 5-10 $\mathrm{mg} \mathrm{C} \mathrm{(=10-20} \mathrm{mg}$ AFDW assuming $50 \% \mathrm{C}$ ) would require about $0.1 \mathrm{mg} \mathrm{C} / \mathrm{L}$ at $4^{\circ} \mathrm{C}$ and a maximum of about $0.8 \mathrm{mg} \mathrm{C} / \mathrm{L}$ at $20^{\circ} \mathrm{C}$ to maintain body weight. Given these values, the concentration of food (in $\mathrm{mg} P O C / \mathrm{L}$ ) at the inner bay site should have been adequate to sustain weight of a standard 15-mm mussel, at least in 1992. Besides 
TABLE 8. Ash-free dry weight for a standard mussel 15-mm in shell length from various lakes. Weights were calculated from weight-length regressions given for fall (October/November) of each year.

\begin{tabular}{lcl}
\hline \hline \multicolumn{1}{c}{ Water Body and Year } & AFDW (mg) & \multicolumn{1}{c}{ Reference } \\
\hline Lake Volkerak, Netherlands, 1989 & 12.1 & Smit and Dudok van Heel (1992) \\
Lake St. Clair (St. 19), 1990 & 10.7 & Nalepa et al. (1993) \\
Hollandsch Diep, 1987 & 9.8 & Smit and Dudok van Heel (1992) \\
Lake IJsselmeer, Netherlands, 1983 & 9.1 & bij de Vaate (1991) \\
Lake St. Clair (St. 19), 1991 & 9.1 & Nalepa et al. (1993) \\
Saginaw Bay (St.5),1991 & 8.6 & This study \\
Haringvliet, Netherlands, 1987 & 7.1 & Smit and Dudok van Heel (1992) \\
Lake St. Clair (St. 3),1990 & 6.9 & Nalepa et al. (1993) \\
Lake St. Clair (St. 3), 1991 & 5.8 & Nalepa et al. (1993) \\
Saginaw Bay (St.5),1992 & 4.6 & This study \\
Saginaw Bay (St.5),1993 & 3.1 & This study \\
\hline
\end{tabular}

food concentration, two other factors that can affect food availability and subsequent utilization by mussels are the rate of food replacement/delivery and food quality. Local depletion of food resources immediately above dense mussel beds is common and the amount of food available is a function of turbulent mixing in the water column (Buss and Jackson 1981, Frechette and Bourget 1985, Petersen and Black 1987). However, it was unlikely that local depletion of food resources occurred at the inner bay site; thermal stratification or vertical chlorophyll gradients were not observed during the study period (Nalepa et al. 1995), indicating a well-mixed water column. Characteristics of the seston that can affect food utilization by Dreissena are particle size (Ten Winkle and Davids 1982, Dorgelo and Smeenk 1988), proportion of inorganic silt (Alexander et al. 1994), and algal composition (Walz 1978b). The decline in weight per unit length and the lack of growth of mussels beyond a specific size in the inner bay may indeed indicate that food quality is poor and utilization limited. For example, the relatively high values of carbon and chlorophyll in late summer 1992 at the inner bay site were apparently associated with a bloom of several species of cyanophytes (Soon-Jin Hwang, personal communication, Kent State University) which apparently are not readily filtered by Dreissena (Gardner et al. 1995, Lavrentyev et al. 1995). Besides a more favorable temperature regime, a higher food quality in the outer bay may have contributed to greater growth compared to the inner bay since cyanophytes were generally not present. At any rate, positive links between food quality, food uti- lization, and variable growth of Dreissena in the bay can only be established through further detailed analysis of seston composition along with field and laboratory studies of Dreissena ingestion and assimilation.

Seasonal variations in soft-tissue weight of a standard $15-\mathrm{mm}$ mussel in the inner bay were quite different in 1992 and 1993, with seasonal declines less apparent in the latter year. Differences in weight of Dreissena over a seasonal period occur relative to the reproductive cycle and/or changes in food levels and temperatures (Skirkyavichena 1970, Walz 1978c, Dorgelo and Smeenk 1988, bij de Vaate 1991, Dorgelo and Kraak 1993, Smit and Dudok van Heel 1992, Garton and Haag 1993, Nalepa et al. 1993). Maximum weight per unit length occurs in the spring (April/May) when the organisms are ripe with gametes. As temperatures increase, spawning is initiated and weight loss occurs throughout the summer months as the gametes are shed; minimum weight occurs in late summer/fall. Weight loss may also occur in the summer because energetic demands are not met as a result of generally high temperatures and low food availability (Walz 1978c, Nalepa et al. 1993). For a seasonal cycle, changes in biomass fit a gaussian distribution with a peak in spring (Smit and Dudok van Heel 1992). Seasonal trends in weight loss of Dreissena in Saginaw Bay followed this general pattern in 1992, but not in 1993. In the latter year, a spring peak was not observed and weight remained constant until a decrease occurred in late summer. If relative weight in the spring and subsequent losses in the summer are any indication of yearly repro- 
ductive potential, reproduction should have been greatly diminished in 1993 compared to 1992. This did not appear to be the case since densities of both larvae and newly-settled juveniles were higher in 1993 than in 1992.

In summary, the initial years of the Dreissena invasion in Saginaw Bay were characterized by large year-to-year variations at individual sites. However, densities at sites with similar substrates were generally consistent throughout the bay by 1993. Although densities and total biomass of the population in 1993 were the lowest of the 3-year sampling period, it is difficult to predict whether the population in the bay has peaked and is now at a level more at equilibrium with its surrounding environment. Food availability has decreased to its lowest level of the 3-year period, length:weight ratios are low, and growth in the inner bay is limited. On the other hand, larval densities have continued to increase over the period and the number of newly-settled juveniles in 1993 was relatively high. All suitable hard substrate appears to be heavily colonized, but colonization of soft sediments remains a long term possibility. While Dreissena populations can fluctuate widely over the long term (Stanczykowska and Lewandowski 1993), values in Saginaw Bay of variables defined as having an influence on population variability (surface area, calcium, phosphate) are within the range found in lakes having relatively constant populations (Ramcharan et al. 1992). Continued monitoring of populations in both the inner and outer bay should provide useful data to better predict population density and growth under differing trophic conditions.

\section{ACKNOWLEDGMENTS}

We thank B. Burns for his help and cooperation during field operations; M. Ford, G. Gostenik, W. Gordon, D. Hartson, P. Hurst, A. Vielmetti, and M. Wimmer for their dedication in counting and sizing the mussels; and K. Stewart, D. Garton, and D. Schloesser for providing helpful comments on the manuscript. This is GLERL Contribution No.943.

\section{REFERENCES}

Alexander, J. E., Jr., Thorp, J. H., and Fell, R. D. 1994. Turbidity and temperature effects on oxygen consumption in the zebra mussel (Dreissena polymorpha). Can. J. Fish. Aquat. Sci. 51:179-184.

Beeton, A. M., Smith, S. H., and Hooper, F. H. 1967. Physical limnology of Saginaw Bay, Lake Huron. Great Lakes Fishery Commission Tech. Rep. 12.
Bierman, V. J., Jr., and Dolan, D. M. 1981. Modeling of phytoplankton-nutrient dynamics in Saginaw Bay, Lake Huron. J. Great Lakes Res. 7:409-439.

bij de Vaate, A. 1991. Distribution and aspects of population dynamics of the zebra mussel Dreissena polymorpha (Pallas, 1771), in the Lake IJsselmeer area (The Netherlands). Oecologia 86:40-50.

Buss, L. W., and Jackson, J. B. C. 1981. Planktonic food availability and suspension-feeder abundance: evidence of in situ depletion. J. Exp. Mar. Biol. Ecol. 49:151-161.

Dermott, R., and Munawar, M. 1993. Invasion of Lake Erie Offshore sediments by Dreissena, and its ecological implications. Can. J. Fish. Aquat. Sci. 50:2298-2304.

Mitchell, J., Murray, I., and Fear, E. 1993. Biomass and production of zebra mussels (Dreissena polymorpha) in shallow waters of Northeastern Lake Erie. In Zebra Mussels: Biology, Impacts, and Control, eds. T. F. Nalepa and D. W. Schloesser, pp. 399-413. Boca Raton, Florida: Lewis Publishers/CRC Press.

Dorgelo, J. 1993. Growth and population structure of the zebra mussel (Dreissena polymorpha) in Dutch lakes differing in trophic state. In Zebra Mussels: Biology, Impacts, and Control, eds. T. F. Nalepa and D. W. Schloesser, pp. 79-94. Boca Raton, Florida: Lewis Publishers/CRC Press.

and Kraak, M. H. S. 1993. Seasonal variation in tissue dry biomass and its relative ash and organic carbon and nitrogen content in the freshwater mussel Dreissena polymorpha (Pallas). Arch. Hydrobiol. 127:409-421.

, and Smeenk, J. W. 1988. Contribution to the ecophysiology of Dreissena polymorpha (Pallas) (Mollusca:Bivalvia): growth, filtration rate, and respiration. Verh. Int. Verein. Theor. Angew. Limnol. 23:2202-2208.

Fahnenstiel, G. L., Lang, G. A., Nalepa, T. F., and Johengen, T. H. 1995. Effects of zebra mussel (Dreissena polymorpha) colonization on water quality parameters in Saginaw Bay, Lake Huron. J. Great Lakes Res. 21:435-448.

Frechette, M., and Bourget, E. 1985. Food-limited growth of Mytilus edulis L. in relation to the benthic boundary layer. Can. J. Fish. Aquat. Sci. 42:1166-1170.

Gardner, W. S., Cavaletto, J. F., Johengen, T. H., Johnson, J. R., Heath, R. T., and Cotner, J. B., Jr. 1995. Effects of the zebra mussel, Dreissena polymorpha, on community nitrogen dynamics in Saginaw Bay, Lake Huron. J. Great Lakes Res. 21:529-544.

Garton, D. W., and Haag, W. R. 1993. Seasonal reproductive cycles and settlement patterns of Dreissena polymorpha in western Lake Erie. In Zebra Mussels: Biology, Impacts, and Control, eds. T. F. Nalepa and 
D. W. Schloesser, pp. 111-128. Boca Raton, Florida: Lewis Publishers/CRC Press.

Griffiths, R. W., Schloesser, D. W., Leech, J. H., and Kovalak W. P. 1991. Distribution and dispersal of the zebra mussel (Dreissena polymorpha) in the Great Lakes region. Can. J. Fish. Aquat. Sci. 48:1381-1388.

Hebert, P. D. N., Wilson, C. C., Murdoch, M. H., and Lazar, R. 1991. Demography and ecological impacts of the invading mollusc, Dreissena polymorpha. Can. J. Zool. 69:405-409.

Holland, R. E. 1993. Changes in planktonic diatoms and water transparency in Hatchery Bay, Bass Island area, Western Lake Erie since the establishment of the zebra mussel. J. Great Lakes Res. 19:617-624.

Hunter, R. D., and Bailey, J. F. 1992. Dreissena polymorpha (zebra mussel): Colonization of soft substrata and some effects on unionid bivalves. Nautilus 106:60-67.

Johengen, T., Nalepa, T. F., Fahnenstiel, G. L., and Goudy, G. 1995. Nutrient changes in Saginaw Bay, Lake Huron, after the establishment of the zebra mussel (Dreissena polymorpha). J. Great Lakes Res. 21:449-464.

Lavrentyev, P. J., Gardner, W. S., Cavaletto, J. F., and Beaver, J. R. 1995. Effects of the zebra mussel (Dreissena polymorpha) on protozoa and phytoplankton from Saginaw Bay, Lake Huron. J. Great Lakes Res. 21:545-557.

Leach, J. H. 1993. Impacts of the zebra mussel (Dreissena polymorpha) on water quality and fish spawning reefs in western Lake Erie. In Zebra Mussels: Biology, Impacts, and Control, eds. T. F. Nalepa and D. W. Schloesser, pp. 381-397. Boca Raton, Florida: Lewis Publishers/CRC Press.

Lewandowski, K. 1991. The occurrence of Dreissena polymorpha (Pall.) in some mesotrophic lakes of the Masurian Lakeland (Poland). Ecol. Pol. 39:273-286.

Mackie, G. L. 1991. Biology of the zebra mussel, Dreissena polymorpha, in relation to native mussels and its potential impact in Lake St. Clair. Hybrobiologia 219:251-268.

MacIsaac, H. J. 1994. Comparative growth and survival of Dreissena polymorpha and Dreissena bugensis, exotic molluscs introduced into the Great Lakes. $J$. Great Lakes Res. 20:783-790.

Sprules, W. G., and Leach, J. H. 1991. Ingestion of small-bodied zooplankton by zebra mussels: Can cannibalism on larvae influence population dynamics? Can. J. Fish. Aquat. Sci. 48:2151-2160.

Marsden, J. E., Trudeau, N., and Keniry, T. 1993. Zebra mussel study of Lake Michigan. Aquatic Ecology Technical Report 93/14, Illinois Natural History Survey.

Mellina, E., and Rasmussen, J. B. 1994. Patterns in the distribution and abundance of zebra mussel (Dreissena polymorpha) in rivers and lakes in relation to substrate and other physicochemical factors. Can. J. Fish. Aquat. Sci. 51:1024-1036.
Nalepa, T. F. 1987. Long term changes in the macrobenthos of southern Lake Michigan. Can. J. Fish. Aquat. Sci. 44:515-524.

, and Schloesser, D. W. (eds.) 1993. Zebra Mussels: Biology, Impacts, and Control. Boca Raton, Florida: Lewis Publishers/CRC Press.

, Cavaletto, J. F., Ford, M., Gordon, W. M., and Wimmer, M. 1993. Seasonal and annual variation in weight and biochemical content of the zebra mussel, Dreissena polymorpha, in Lake St. Clair. J. Great Lakes Res. 19:541-552.

Fahnenstiel, G. L., McCormick, M. J., Cavaletto, J. F., Fanslow, D., Ford, M., Gordon, W. M., Goudy, G., Johengen, T., Jude, D., Lang, G. A., and Wojcik, J. A. in press. Physical and chemical variables of Saginaw Bay, Lake Huron in 1991-93. NOAA Data Report.

Nicholls, K. H., and Hopkins, G. J. 1993. Recent changes in Lake Erie (north shore) phytoplankton: cumulative impacts of phosphorus loading reductions and the zebra mussel introduction. J. Great Lakes Res. 19:637-647.

Peterson, C. H., and Black, R. 1987. Resource depletion by active suspension feeders on tidal flats: influence of local density and tidal elevation. Limnol. Oceanogr. 32:143-166.

Ramcharan, C. W., Padilla, D. K., and Dodson, S. I. 1992. A multivariate model for predicting population fluctuations of Dreissena polymorpha in North American lakes. Can. J. Fish. Aquat. Sci. 49:150-158.

Robbins, J. A. 1980. Sediments of Saginaw Bay, Lake Huron: elemental composition and accummulation rates. Special Report No. 102. Great Lakes Research Division, University of Michigan, Ann Arbor, MI.

Russell-Hunter, W. D. 1985. Physiological, ecological, and evolutionary aspects of molluscan tissue degrowth. Amer. Malacol. Bull. 3:213-221.

Browne, R. A., and Aldridge, D. W. 1984. Overwinter tissue degrowth in natural populations of freshwater snails (Helisoma trivolis and Lymnaea palustris). Ecology 65:223-229.

Schneider, D. W. 1992. A bioenergetics model of zebra mussel, Dreissena polymorpha, growth in the Great Lakes. Can. J. Fish. Aquat. Sci. 49:1406-1416.

Sebestyen, O. 1938. Colonization of two new faun-elements of Pontus-origin (Dreissena polymorpha Pall. and Corophium curvispinum G. O. Sars forma devium Wundsch) in Lake Balaton. Verh. Internat. Verein. Limnol. 8:169-82.

Skirkyavichena, Z. Y. 1970. The regularities of weight of the Dreissena. II. The seasonal effect. Trud. Akad. NAUK Litov. SSR. Ser. C. 2:91-97.

Smit, H., and Dudok van Heel, E. 1992. Methological aspects of a simple allometric biomass determination of Dreissena polymorpha aggregations. In The zebra mussel Dreissena polymorpha: ecology, biological monitoring and first applications in the water quality 
mangement, eds. D. Neumann and H. A. Jenner, pp. 79-86. New York: Gustav Fisher Verlag. bij de Vaate, A., and Fioole, A. 1992. Shell growth of the zebra mussel (Dreissena polymorpha Pallas) in relation to selected physico-chemical parameters in the Lower Rhine and some associated lakes. Arch. Hydrobiol. 124:257-280.

Smith, V. E., Lee, K. W., Filkins, J. C., Hartwell, K. W., Rygwelski, K. R., and Townsend, J. M. 1977. Survey of chemical factors in Saginaw Bay (Lake Huron). Ecological Research Series. EPA-600/3-77-125. Environmental Protection Agency, Duluth, MN.

Sprung, M. 1989. Field and laboratory observations of Dreissena polymorpha larvae: abundance, growth, mortality, and food demands. Arch. Hydrobiol. 115:537-561.

1993. Observations on shell growth and mortality of Dreissena polymorpha in lakes. In The Zebra Mussel Dreissena polymorpha: Ecology, Biological Monitoring and First Applications in the Water Quality Management, eds. D. Neumann and H. A. Jenner, pp. 19-28. New York, New York: Gustav Fisher.

Stanczykowska, A. 1964. The relationship between abundance, aggregations, and "condition" of Dreissena polymorpha Pall. in 36 Mazurian lakes. Ekol. Pol. Ser. A 12:653-690.

1984. The effect of various phosphorus loadings on the occurrence of Dreissena polymorpha (Pall.). Limnologica (Berlin) 15:535-539.

, and Lewandowski, K. 1993. Thirty years of

Dreissena polymorpha ecology in Mazurian Lakes of northeastern Poland. In Zebra Mussels: Biology, Impacts, and Control, eds. T. F. Nalepa and D. W. Schloesser, pp. 3-33. Boca Raton, Florida: Lewis Publishers/CRC Press.

, Schenker, H. J., and Fafara, Z. 1975. Comparative characteristics of populations of Dreissena polymorpha (Pall.) in 1962 and 1972 in 13 Mazurian Lakes. Bull. Acad. Pol. Sci. II. 23:383-390.

Stewart, T. W., and Haynes, J. M. 1994. Benthic macroinvertebrate communities of southwestern Lake
Ontario following invasion of Dreissena. J. Great Lakes Res. 20:479-493.

Stoermer, E. F., and Theriot, E. 1985. Phytoplankton distribution in Saginaw Bay. J. Great Lakes Res. 11:132-142.

Ten Winkle, E. H., and Davids, C. 1982. Food selection by Dreissena polymorpha Pallas (Mollusca: Bivalvia). Freshwater Biol. 12:553-558.

Walz., N. 1974. Ruckgang der Dreissena polymorphapopulation im Bodensee. Gas und Wasserfach Wasser/Abwasser 115:20-24. 1978a. The energy balance of the freshwater mussel Dreissena polymorpha Pallas in laboratory experiments and in Lake Constance. III. Growth under standard conditions. Arch. Hydrobiol./Suppl. 55:121-141.

. 1978b. The energy balance of the freshwater mussel Dreissena polymorpha Pallas in laboratory experiments and in Lake Constance. IV. Growth in Lake Constance. Arch. Hydrobiol./Suppl. 55:142-156. . 1978c. The energy balance of the freshwater mussel Dreissena polymorpha Pallas in laboratory experiments and in Lake Constance. V. Seasonal and nutritional changes in the biochemical content. Arch. Hydrobiol./Suppl. 55:235-254. 1978d. Die production der Dreissena-population und deren bedeutung im stoffkreislauf des Bodensees. Arch. Hydrobiol. 82:482-499.

Winnell, M. H., and Jude, D. J. 1987. Benthic community structure and composition among rocky habitats in the Great Lakes and Keuka Lake, New York. $J$. Great Lakes Res. 13:3-17.

Wood, L. E. 1964. Bottom sediments of Saginaw Bay, Michigan. J. Sediment. Petrol. 34:173-184.

Wu, L., and Culver, D. A. 1991. Zooplankton grazing and phytoplankton abundance: an assessment before and after invasion of Dreissena polymorpha. J. Great Lakes Res. 17:425-436.

Submitted: 7 February 1995

Accepted: 2 June 1995 